Article

\title{
Can China's Agricultural FDI in Developing Countries Achieve a Win-Win Goal?-Enlightenment from the Literature
}

\author{
Xiaoyu Jiang ${ }^{1}$, Yangfen Chen ${ }^{1, *}$ and Lijuan Wang ${ }^{2}$ \\ 1 Institute of Agricultural Economics and Development, Chinese Academy of Agricultural Sciences, \\ Beijing 100081, China;chenyangfen@caas.cn \\ 2 Institute of Rural Development, Zhejiang Academy of Agricultural Sciences, Hangzhou 310021, China; \\ wanglj1981@126.com \\ * Correspondence: chenyangfen@caas.cn; Tel.: +86-010-82106162
}

Received: 7 December 2018; Accepted: 17 December 2018; Published: 21 December 2018

\begin{abstract}
Since 2014, there have been increasing numbers of undernourished people in the world, mainly distributed in developing countries. At the same time, the rapid growth of China's agricultural FDI (Foreign Direct Investment) has attracted international attention. There are different opinions on whether China's fast-growing agricultural investment can contribute to promoting global food security. The objective of the article is to clarify the consensus and differences of current research, and explore the actual impacts of China's agricultural FDI. This paper adopts the Grounded Theory to sort out the characteristics, reasons, and impacts of China's agricultural FDI and their intrinsic relationship. The results show that private enterprises are the mainstay of China's agricultural FDI, mainly concentrated in developing countries in Asia and a few developed countries such as Singapore, New Zealand, and the United States. As the investment model is transformed from land leasing to mergers and acquisitions, China's agricultural investment links are transformed from planting to full-industry chain operations. The motives of Chinese agricultural FDI are affected by corporate goals, national strategies, and the international environment. For China, overseas agricultural investment guarantees national food security, helps expand the agricultural product market, and enhances China's influence. For the host country, China's agricultural investment brings about agricultural technology, management experience, and employment opportunities. However, in the actual investment process, the investment model of land leasing has caused the instability of local farmers' livelihoods, and the excessive pursuit of profits by Chinese companies has also led to an unfair distribution of agricultural products. All of these may bring some challenges to the social and economic development of the host country to a certain extent, affecting the realization of win-win goals. In order to achieve a win-win goal, at the enterprise level, Chinese companies should make the investment model fit the interests and development goals of the host country, rationally choose the investment location, and abide by local rules. At the government level, the Chinese government should guide enterprises to focus on the less developed countries and regions that are most in need of introducing agricultural investment, and provide enterprises with risk protection. At the international level, it is necessary to strengthen the formulation and improvement of international agricultural investment rules, guide the public to form an objective understanding of agricultural investment behavior and impact, and create a suitable environment for international agricultural investment.
\end{abstract}

Keywords: agricultural FDI; agriculture "going global"; China; win-win goal; The Grounded Theory 


\section{Introduction}

In recent years, the issue of food security in developing countries has received extensive attention [1,2]. According to the recent Food Security and Nutrition Status 2018 Report released by the Food and Agriculture Organization of the United Nations (FAO), in 2017, the number of undernourished people is estimated to have increased to 821 million. The situation in most regions of South America and Africa is deteriorating; likewise, the decline in the number of undernourished people in Asia is showing signs of diminishing [3]. Due to the constraints of agricultural technology and extreme weather, the food production in developing countries is insufficient and requires a large amount of agricultural investment [4,5]. According to FAO projections, an average of $\$ 209$ billion in annual investment is required to meet the projected agricultural demand of 93 developing countries in 2050 [6]. Since most of the less developed countries have limited agricultural investment capacity, they need to rely on overseas agricultural investment to meet their development needs [7].

From a practical point of view, developed countries have long been the main source of FDI $[8,9]$. They use the entire industry chain to dominate the global agricultural market. With the development of the world economy, developing countries, especially China, have gradually become important investment sources and have received the attention of the international community [10]. With the rise of national power and the pressure of food security, China has continuously expanded its investment scale $[4,11]$. According to official statistics, the net FDI of China's agriculture increased from 190 million dollars in 2006 to 3.29 billion dollars in 2016, an average annual increase of 33.0\%.

In response to this increasingly important investor, China's growing agricultural FDI will either help resolve world food security issues, or exist as a form of neo-colonialism that remains controversial. Some people think that China's agricultural investment has solved the problem of shortage of funds [11], promoted the transfer of agricultural technology [12], and thus improved the efficiency of agricultural production in developing countries [4]. It has given new development momentum to the agricultural and rural areas of these less developed countries, and has effectively guaranteed food security $[5,13]$. On the contrary, some studies also believe that this new allocation of resources, capital, and rights is a kind of "neo-imperialism" [4]. It is just a new model to duplicate the previous pattern of resource exploitation and predation [14]. Agricultural FDI is a means for China to rely on the resources of developing countries to support itself [15]. Others believe that the actual impact of China's large-scale agricultural FDI on host countries and the international community is more complicated than those described in these international studies and reports [16,17].

There are several main reasons for this inconsistency. Firstly, agricultural investment data is difficult to obtain due to the opaqueness of agricultural investment projects [18]. Secondly, the inconsistency of agricultural FDI statistics is also an important reason for this controversy. For example, the transactions reported in some studies and databases are not really realized, and the number of unfinished transactions accounts for a large proportion of the statistics [19]. These reasons have led to the media's expansion of the scale of China's agricultural FDI [20]. In addition, most of the current research is directed at a single aspect of China's investment motives, investment patterns, and impact on food security. Additionally, the research is mainly focused on China's agricultural investment in Africa. For example, Chichava studied the policies, methods, and motives of agricultural investment between China and Brazil in Mozambique, and compared the similarities and differences between the Chinese approach and the Brazilian approach [4]. Amanor examined the relationship between China's agricultural investment and China's interests in Ghana, and discussed the impact of China's agricultural investment on Ghana's agriculture and society [11]. Buckley explores the discourses, justifications, and critiques of agricultural cooperation between China and Africa on the basis of reviewing documents and interviewing 30 informants, and believes that a more nuanced understanding of Chinese motivations can support constructive and active engagement by African partners with China [19].These studies have enriched the perception of China's agricultural FDI from different angles, but it is difficult to show its full picture from a single perspective. From the research content, these studies pay more attention to the unilateral impact of Chinese agricultural foreign 
investment on China or the host country. There are few studies on the impact of Chinese agricultural FDI on both sides. From the research method, the current research mostly adopts the method of case analysis. Although this method makes the research results more thorough and typical, it is still to be studied whether the conclusions are universal. For the actual impact of China's agricultural FDI, multi-level and multi-angle systematic research based on a large amount of literature is still insufficient. The current research on the role and impact of Chinese agricultural FDI is still unclear.

In 2015, the UN released the 2030 Sustainable Development Goals report, which aims to eliminate hunger, achieve food security, and promote sustainable agricultural development. This requires developing countries to introduce foreign investment and improve agricultural production capacity. For China, the "Agriculture Going Global" strategy from 2006, to the "One Belt, One Road" initiative in 2013 has injected new vitality into China's overseas investment. China has built a new mechanism for agricultural foreign cooperation from the national level and participated in the global governance of agriculture with a more proactive attitude [21]. Whether China's fast-growing agricultural FDI can meet the development needs of China and developing countries and whether it can achieve the UN's sustainable development goals is a question worth studying.

The purpose of this article is to verify whether China's agricultural FDI can meet the needs of developing countries and achieve a win-win situation by analyzing the status, motivation, and impact of China's agricultural FDI. Based on the above background and current research results, we propose several research questions. What is the actual situation of China's agricultural FDI? What is the difference between Chinese agricultural FDI and FDI theory? Why is there a gap between the actual effects and goals of China's agricultural FDI? What can be done to make China's agricultural FDI in developing countries meet the needs of both sides and achieve a win-win goal? Apart from the Introduction section, we will start with a description of the methodological approach and the literature sources. On this basis, we will integrate current research views, and conduct an in-depth analysis of the characteristics, causes and impacts of China's agricultural FDI from the macro, meso, and micro levels, and propose countermeasures to optimize the effects of agricultural investment in developing countries and achieve a win-win goal. Finally, we will summarize the research findings and corresponding policy recommendations for China's agricultural FDI.

\section{Theories, Methods and Data}

\subsection{Theories of FDI}

Because China's agricultural FDI is essentially a category of FDI, in order to more clearly analyze the development characteristics, motives, and impacts of China's agricultural FDI, it is necessary to sort out the development of FDI theory.

\subsubsection{FDI Theories from Developed Countries}

Early research on FDI was mainly concentrated in developed countries. As these countries realized the industrial revolution earlier, they accumulated excess capital. FDI began with the motivation to seek higher profit margins. The mainstream FDI theory in developed countries can be divided into four research schools.

The use of modern economic analysis methods to study FDI began in the 1960s, and the first was the research school based on the theory of industrial organization, including monopolistic advantage theory and oligopolistic reaction theory, among others. Hymer's (1960) [22] theory of monopolistic advantage elaborates on the monopolistic advantages of FDI enterprises such as technology, economies of scale, capital and currency, and organizational management capabilities. Knickerbocker (1969) [23] expands the theory of monopoly advantage from the perspective of mutual behavior between oligopolistic companies, and puts forward the oligopolistic reaction theory. He believes that once the oligopolistic enterprise takes any action, other companies will respond. This school has made 
a groundbreaking contribution to the construction of the FDI theoretical system. It can explain the phenomenon of an enterprises' FDI, but there is no explanation for the motivation of investment.

The school of research based on international trade theory explains the changes in international trade and international investment models. Its representatives are international product life cycle theory and comparative advantage theory, among others. The international product life cycle theory was proposed by Vernon (1966) [24]. It explains the motivation of FDI from the perspective of different stages of product development, and reveals that FDI enterprises should consider the location advantage of the host country. Kojima's (1978) [25] comprehensive advantage theory believes that FDI should follow industries in which the country has or will be at a relatively disadvantageous level. The theory of dynamic location advantage proposed and developed by Dunning et al. (1977) [26] believes that the location advantage of the host country is a necessary condition for multinational companies to carry out FDI.

The school of research based on internalization theory, explains why multinational corporations need to establish an internal market through FDI to coordinate international division of labor. Its representatives are Buckley et al. (1976) [27] and Rugman's (1987) [28] internalization theory. The theory holds that when the market for intermediate products is incomplete, it is possible for companies to replace external markets with internal markets in order to pursue greater profits and to manage business activities in a unified manner. When internalization transcends national borders, multinational corporations are created.

The school of research based on comprehensive theory combines multiple theories of FDI, and its interpretation of FDI is broader. Its representatives are international production eclectic theory, competitive advantage theory, and international market entry choice eclectic theory. Dunning's (1977) [29] eclectic theory of international production provides a more comprehensive analysis of the motivations and determinants of FDI. It believes that if a company has ownership advantages, internalization advantages, and location advantages, then the company can make FDI. Porter's (1990) $[30,31]$ competitive advantage theory believes that fierce domestic competition leads to FDI and is a guarantee of FDI success. The eclectic theory of choice of international market entry proposed by Hill et al. $(1990)[32,33]$ believes that the choice of internationalization of multinational corporations depends on four factors: strategic variables, location variables, trading variables, and corporate ownership dominant variables.

\subsubsection{FDI Theories from Developing Countries}

In the late 1970s, the rise of FDI in developing countries received the attention of researchers and produced many valuable theories. Representative theories include development stage theory, small-scale technology theory, localized technological change theory, and technological competence theory.

According to Dunning's (1981) [34] development stage theory, FDI in developing countries depends on the country's economic development stage and its ownership, internalization, and location advantages. The theory of small-scale technology by Louis (1983) [35] argues that the advantages of FDI in developing countries are small-scale manufacturing, local procurement, and proximity to markets. The theory of localized technological change, proposed by Lall et al. (1983) [36], argues that technological changes in developing countries can give them a competitive advantage. The theory of technological competence proposed by Cantwell (1989) [37] believes that the FDI of developing countries follows the sequence geographically from neighboring regions to developing countries to developed countries. 
In general, from the theoretical basis, the mainstream FDI theory in developed countries has developed rapidly since Hymer and various new theories have been produced continuously, however, no single theory can systematically explain this complicated issue [38]. The FDI theory of developing countries, from the theoretical basis and research perspective, follows Hymer's monopoly advantage to a certain degree. From the perspective of the fields involved, the FDI theory of both developed and developing countries focuses on the non-agricultural sector. Because agricultural investment has the characteristics of high investment risk and long investment period, and as China is the largest developing country, whether its agricultural FDI has different rules is worthy of further study at the theoretical level.

\subsection{Methods}

We used the research path of grounded theory to conduct this research. Grounded theory is a qualitative analysis method for summarizing phenomena, which bridges the gap between theory and data. On the basis of empirical data, current literature, and the personal experience of researchers, through induction, comparison, and analysis, the concepts are gradually generated, the logical relationship is clarified, and finally a new concept or theory is formed [39,40]. This paper analyzes whether China's agricultural FDI can meet the needs of China and developing countries and achieve a win-win goal. From a macro perspective, China's agricultural foreign investment involves political, economic, and social fields in China and the host country. From a micro level, China's agricultural foreign investment involves multiple investment entities, different investment links, and investment methods. The structures, processes, strategies, and other implicit relationships between the various factors are complex in this research. It is difficult to study through mathematical assumptions and mathematical statistics. In addition, for the impact of China's agricultural FDI, the current multi-level qualitative research based on a large amount of literature is still insufficient, and it is necessary to conduct macro and micro level analysis.

The grounded theory was developed by Glaser and Strauss in the 1960s as a qualitative research method [39]. Based on the systematic collection of data, the researchers search for the core concepts that reflect the nature of the phenomenon of things, and then construct related social theories through the connection between these concepts. Step-by-step coding of data is the most important part of grounded theory, including three levels of coding. The first-level coding (Open Coding) is a process of breaking up the collected data, discovering the concept from the data, and naming and classifying the phenomenon of the research. The primary task of secondary coding (Axial Coding) is to discover and establish relationships between concept categories to represent the organic associations between the various parts of the data. Each time the researcher conducts an in-depth analysis of only one category, considers the association between the concept families themselves, and explores the intentions and motivations of the researchers who express these concept categories. The third-level of coding (Selective Coding) is to select "core categories" after systematic analysis in all discovered concept categories, and the analysis is continually concentrated on those code numbers associated with the core categories. The specific analysis process is shown in Figure 1. As a bottom-up approach, grounded theory is considered to be particularly suitable for complex, action-oriented social interaction processes. Therefore, it is appropriate to use the grounded theory method to study the issue of China's agricultural FDI. 


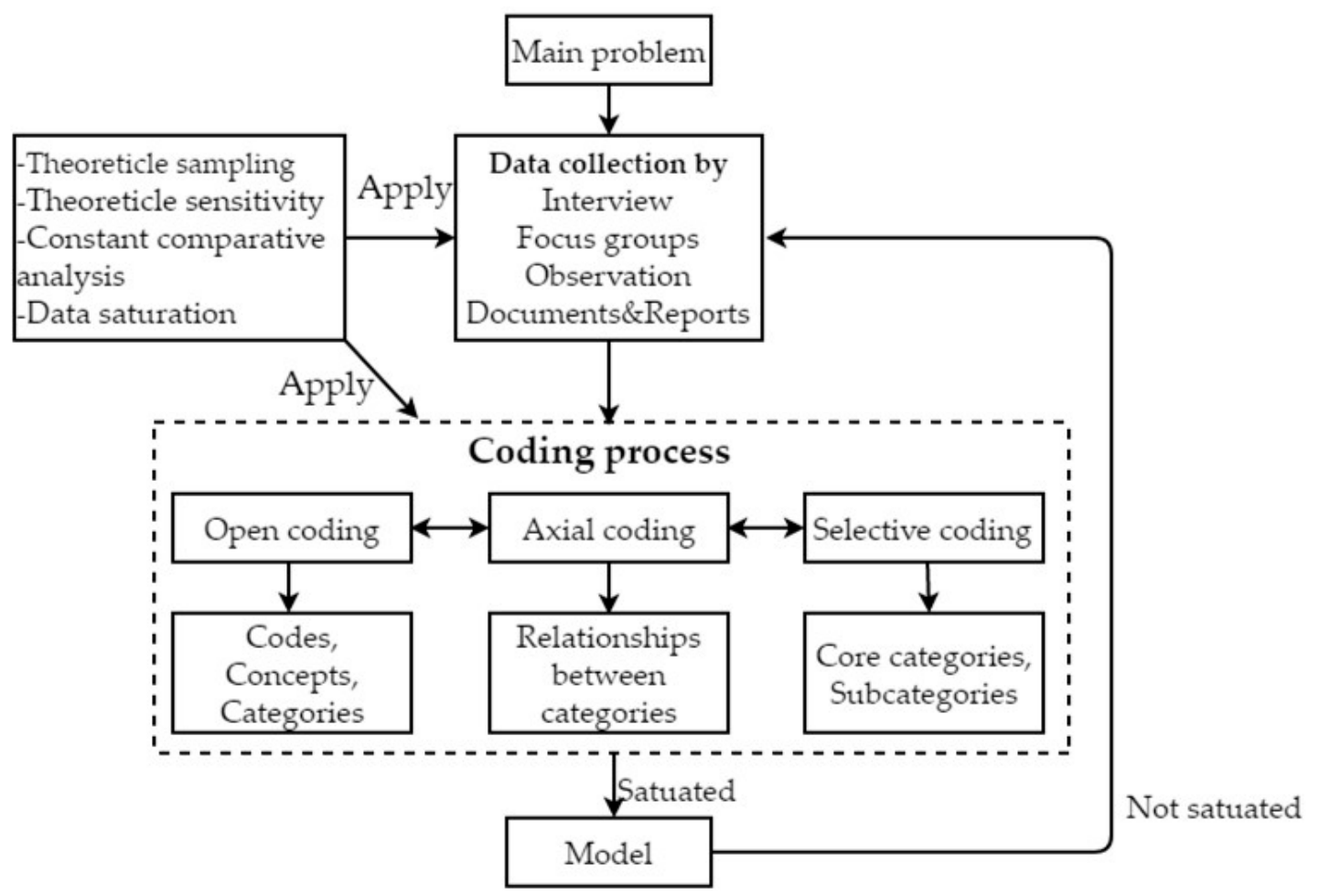

Figure 1. Framework of the grounded theory method (adapted from [41]).

\subsection{Data Collection}

In order to fully consider the views of scholars and public opinion on China's agricultural FDI, the literature used in this analysis includes academic articles and media reports. At the same time, we also use some reliable data to verify the results of these analyses.

We chose Web of Science as the source of academic articles. Web of Science is a large, comprehensive, multidisciplinary, core journal citation index database that includes more than 8000 of the world's most influential, high-quality journals reviewed by peer experts. The articles it contains are relatively complete and influential, and suitable for in-depth analysis. Despite this, we cannot guarantee that all academic articles were collected. With the theme of "China, agricultural foreign investment", "China, agricultural foreign aid", and "China, agriculture South-South Cooperation", 268, 58 , and 9 articles were retrieved, respectively. For academic articles that are not closely related to the topic, we have read roughly 162 articles. As far as the nationality of these authors is concerned, there are from China, Zimbabwe, Ghana, Mozambique, and other target countries for Chinese agricultural FDI. In addition, some of these authors are from the United States, Britain, Italy, Germany, the Netherlands, and other developed countries. As for the affiliations of the authors, there are some international institutions, such as the International Food Policy Research Institute, FAO, as well as some colleges and universities, such as the University of Sussex, the University of Groningen, and more. As far as the source of the article is concerned, these articles are from different journals such as Journal of Peasant Studies, World Development, and Food Security. All of this allows us to understand the different voices of supporters, opponents, stakeholders, and non-stakeholders, and prevent us from having a partial approach to the conclusion. In particular, we list some academic articles and their main points of relevance to this article, as shown in Table 1.

In order to fully grasp the internal logic of China's agricultural foreign investment, we also paid attention to some media reports from Microsoft Bing Search (international version). On July 9, 2018, the search was again conducted under the theme of "China, agricultural foreign investment", "China, agricultural foreign aid", and "China, agriculture South-South Cooperation", with 3.18 million reports, 2.45 million reports, and 8.11 million reports, respectively. We selected the first ten pages of research 
and excluded duplicate reports, with a total of 216 to analyze. Although the media coverage we use for analysis is only a small part of all reports, the main point of view on China's agricultural FDI is basically saturated, and there may be some unconsidered, but no missing, key information.

In addition, we have used official Chinese data to support our views. All data in Chapter 3.3 are from the Report on China's Agricultural Foreign Investment Cooperation, issued by the Ministry of Agriculture and Rural Affairs of the People's Republic of China. Because the company's foreign agricultural investment information collection work began in 2013, this paper uses the data from 2013 to 2016. Through the collection of these documents, we have basically mastered important information about China's agricultural FDI, and did not miss key information, laying the foundation for the next model building.

In order to take into account the views of scholars, media, and public opinion, we have included relevant academic articles and media reports in the scope of analysis. In the literature collection process, we hold impartiality in the selection of papers. Although this method is difficult to include all relevant literature, this large sample-based analysis can take into account different sounds, avoiding subjective assumptions to a certain extent. In the literature interpretation process, we put forward the author's original words into the analysis part of the manuscript, enriched the content of the article, and put forward our conclusions on this basis. In addition, we handed over the collected literature to our colleagues for review. Based on their comments, we corrected the results of the analysis and used official data to verify these conclusions. Therefore, the conclusions presented in this article are basically objective and can reflect the general situation of China's agricultural FDI.

Table 1. Review of selected research results on the impact of China's agricultural FDI.

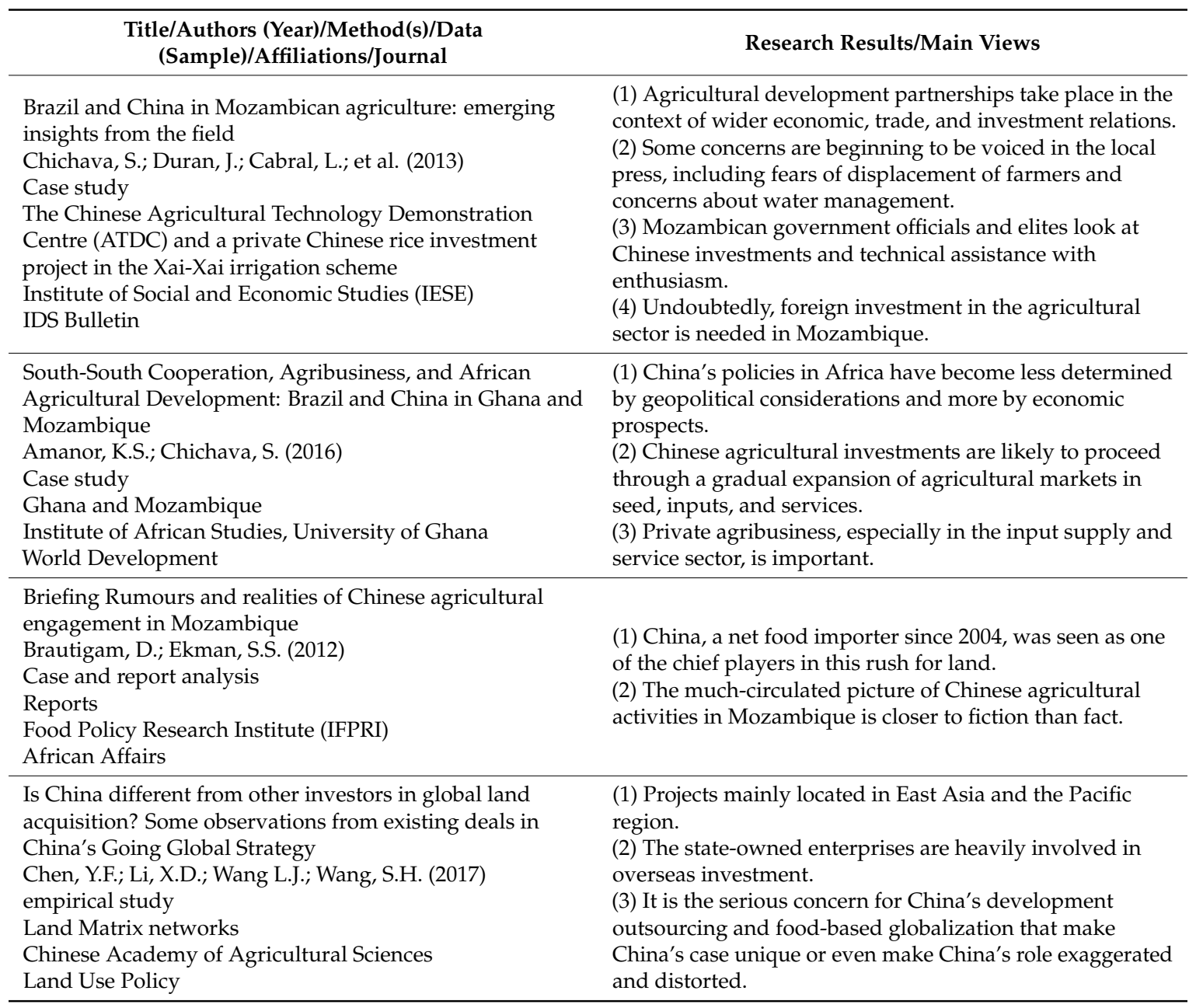


Table 1. Cont

Title/Authors (Year)/Method(s)/Data

(Sample)/Affiliations/Journal

A New Politics of Development Cooperation? Chinese and Brazilian Engagements in African Agriculture

Scoones, I.; Amanor, K.; Favareto, A.; et al. (2016)

Case study and empirical investigation

Four countries in Africa, as well as China and Brazil

Institute of Development Studies (IDS), University of Sussex

World Development

Global land and water grabbing

Rulli, M.C.; Saviori, A.; D'Odorico, P. (2013)

Empirical study

Grain

Department of Hydraulics, Roadways, Environmental, and

Surveying Engineering

Proceedings of The National Academy of Sciences of The

United States of America

China-Africa development cooperation in the rural sector: an exploration of land tenure and investments linkages for sustainable resource use

Zhao, Y. (2013)

Document analysis

Academic publications and policy reports

Globalisation Studies Groningen, Faculty of Arts, University

of Groningen

Environment, Development and Sustainability

Reviving Zimbabwe's Agriculture: The Role of China and Brazil

Mukwereza, L. (2013)

Case study

Tobacco and cotton sectors

Department of AGRITEX, Ministry of Agriculture IDS Bulletin

Feeding more people on an increasingly fragile planet:

china's food and nutrition security in a national and global

Context

Fan, S.; Brzeska, J. (2014)

Data analysis

FAO and World Bank

International Food Policy Research Institute

Journal of Integrative Agriculture

China's 'Developmental Outsourcing': A critical examination

of Chinese global 'land grabs' discourse

Hofman, I.; Ho, P. (2012)

Data analysis

Land-based investments in terms of incidence, size and

geographical dispersion over 1949-2011

Leiden University

Journal of Peasant Studies

Research Results/Main Views

(1) A strong diplomatic push to assert geopolitical influence was central, and aid and investment was seen as part of this. (2) Chinese involvement in African agriculture therefore reflects China's own policy narratives and imperatives, and is driven by a range of factors, often with strong state involvement.

(3) For African politicians and business elites, a new source of investment offers new opportunities, and is widely welcomed.

(4) Africa has long waited for investment in agriculture and associated productive sectors.

(1) Land grabbing is a measure used by some governments (and corporations) to meet their food and energy requirements by acquiring land in a foreign country.

(2) Some of the countries affected by land grabbing exhibit

relatively high levels of malnourishment.

(3) Land and water grabbing enhance food and energy availability in the grabbing country.

(4) Although land grabbing is mainly because of food

demand, other drivers, such as biofuel demand and financial speculations, also play a role.

(1) The shift of China's Africa policy with a stronger focus on agricultural cooperation resonates with China's rising food demand.

(2) Food shortages and rising food prices have contributed to

China's increased dependence on grain imports.

(3) In particular, large-scale commercial agriculture poses a

direct threat to locally managed customary land tenure systems in large parts of Africa.

(4) Linking these investments with sustainable resource use and livelihoods of local communities is necessary to generate more inclusive investment outcomes.

(5) They need to understand how land tenure systems work and the underlying social and cultural practices in relation to development and governance, in order to gain further insights into the local complexities.

(1) Chinese companies provide key inputs that the beneficiaries repay at the time of marketing the produce. (2) Opportunities for rent-seeking by officials, as well as selective bypassing of regulations by Chinese investors, have been noted by many commentators.

\footnotetext{
Note: The choice of papers in the table is mainly to see the relevance of this article and the frequency of citations. In

order to save the length of the paper, we have only selected 10 representative papers and listed their main points.
}

(1) China has the opportunity to increase food and nutrition security both nationally and globally.

(2) China has the opportunity to improve food and nutrition security within and beyond its borders.

(3) China is an increasingly influential actor within the global food and nutrition security network.

(1) The discourse on Chinese "land grabs" is insufficiently informed by the available data.

(2) China's overseas land-based investments are part of what can be termed "developmental outsourcing". 


\section{Conceptual Refinement and Model Building}

\subsection{Open Coding}

In the open decoding stage, we always focus on the core research issue of "China's agricultural foreign investment behavior". Based on the original intention of the articles, we tried to refine the author's point of view. In this process, the meaningful sentences are decomposed word by word, especially those that can be used as code numbers, and then the initial concepts of repetition or overlap in this sense are combined, to find the concept that best represents the connotation of the phenomenon. In this paper, 236 statements and 72 initial concepts were extracted in the conceptualization stage, and the concepts are named by the keywords of the statements or according to the meaning of the sentences. Considering that the initial concept is large in number and there is a certain degree of intersection, according to the research needs and the relationship between causality, similarity, type, and subordination between the concepts, concepts related to the same phenomenon are clustered into one category. In the end, a total of 15 concept categories (Tables 2 and 3) were formed, which were investment regions, investment subjects, investment links, investment methods, investment profit, agricultural assistance, geopolitics, social economy, international environment, industry development, national development, international influence, support and guidance, cooperation and communication, and media guide. In particular, we have listed Tables 2 and 3 to demonstrate our research process. In Table 2, we present three examples to illustrate how we can generalize these statements or phenomena into initial concepts and then cluster these concepts into conceptual categories.

Table 2. Example of conceptualization.

\begin{tabular}{|c|c|c|}
\hline Phenomena/Statements & Concepts & Concept Categories \\
\hline $\begin{array}{l}\text { Large number of private enterprises, } \mathrm{a}_{11}, \ldots \\
\text { State-owned enterprises are important subjects, } \mathrm{a}_{12}, \ldots \\
\text { Individual investment in small plantations, } \mathrm{a}_{13}, \ldots \\
\text { Financial institutions have provided large amounts of } \\
\text { commercial loans to African countries, } \mathrm{a}_{14}, \ldots \\
\text { China's overseas investment involves investment funds, } \mathrm{a}_{15} \text {, } \\
\ldots\end{array}$ & $\begin{array}{l}A_{11} \text { Private enterprises }\left(a_{11} \ldots\right) \\
A_{12} \text { State-owned enterprises }\left(a_{12}\right. \\
\ldots) \text {, } \\
A_{13} \text { Individual investment }\left(a_{13} \ldots\right. \\
), \\
A_{14} \text { Financial institutions }\left(a_{14} \ldots\right) \text {, } \\
A_{15} \text { Investment funds }\left(a_{15} \ldots\right)\end{array}$ & $\begin{array}{l}\mathrm{AA}_{2} \text { Investment subjects } \\
\left(\mathrm{A}_{11}-\mathrm{A}_{15}\right)\end{array}$ \\
\hline
\end{tabular}

A new source of investment offers new economic growth

opportunities, $\mathrm{a}_{49}, \ldots$

The plantations generated some employment opportunities for daily wage work, $a_{50}, \ldots$ promoted the transformation of local agricultural products market, $\mathrm{a}_{51}, \ldots$

Opportunities for rent-seeking by officials, as well as selective bypassing of regulations by Chinese investors have been noted by many commentators, $a_{52}, \ldots$.

with no consideration of the social and environmental impacts, $a_{53}, \ldots$

The investors might leave the plantations before the contract finished and ignore the distribution of food, $\mathrm{a}_{54}, \ldots$

The development of the agricultural sector in the host country can increase taxes for the government, $\mathrm{a}_{55}, \ldots$

Note: In order to save the length of the paper, this table takes threeconcept categories as examples, and lists their corresponding concepts and phenomena. This includes both positive and negative evaluations.Each concept here uses only one phenomenon as a case, and other phenomena are represented by "...".

$\mathrm{A}_{49}$ Economic growth $\left(\mathrm{a}_{49} \ldots\right)$ $\mathrm{A}_{50}$ Employment opportunities $\left(a_{50} \ldots\right)$

$\mathrm{A}_{51}$ Market reform $\left(\mathrm{a}_{51} \ldots\right)$ $A_{52}$ Vicious competition $\left(a_{52} \ldots\right)$ $\mathrm{A}_{53}$ Environmental pollution ( $\mathrm{a}_{53}$ ...)

$A_{54}$ Food distribution $\left(a_{54} \ldots\right)$

$A_{55}$ Increase in taxes $\left(a_{55} \ldots\right)$
$\mathrm{AA}_{11}$ National development $\left(\mathrm{A}_{49}-\mathrm{A}_{55}\right)$ 
Table 3. Concepts and concept categories from open coding.

\begin{tabular}{|c|c|}
\hline Concept Categories & Concepts \\
\hline $\mathrm{AA}_{1}$ Investment regions $\left(\mathrm{A}_{1}-\mathrm{A}_{10}\right)$ & $\begin{array}{l}\mathrm{A}_{1} \text { Asia, } \mathrm{A}_{2} \text { Geographic distance, } \mathrm{A}_{3} \text { Africa, } \mathrm{A}_{4} \text { Resource } \\
\text { oriented, } \mathrm{A}_{5} \text { Latin America, } \mathrm{A}_{6} \text { Investment conditions, } \mathrm{A}_{7} \\
\text { Investment risks, } \mathrm{A}_{8} \text { Developed countries, } \mathrm{A}_{9} \\
\text { Technology-oriented, } \mathrm{A}_{10} \text { Market-oriented }\end{array}$ \\
\hline $\mathrm{AA}_{2}$ Investment subjects $\left(\mathrm{A}_{11}-\mathrm{A}_{15}\right)$ & $\begin{array}{l}\mathrm{A}_{11} \text { Private enterprises, } \mathrm{A}_{12} \text { State-owned enterprises, } \mathrm{A}_{13} \\
\text { Individual investment, } \mathrm{A}_{14} \text { Financial institutions, } \mathrm{A}_{15} \\
\text { Investment funds }\end{array}$ \\
\hline $\mathrm{AA}_{3}$ Investment links $\left(\mathrm{A}_{16}-\mathrm{A}_{20}\right)$ & $\begin{array}{l}\mathrm{A}_{16} \text { Planting, } \mathrm{A}_{17} \text { Processing, } \mathrm{A}_{18} \text { Warehousing, } \mathrm{A}_{19} \text { Logistics, } \\
\mathrm{A}_{20} \text { The whole industry chain }\end{array}$ \\
\hline $\mathrm{AA}_{4}$ Investment ways $\left(\mathrm{A}_{21}-\mathrm{A}_{23}\right)$ & $\mathrm{A}_{21}$ Land lease, $\mathrm{A}_{22}$ Contract agriculture, $\mathrm{A}_{23}$ Merger \\
\hline $\mathrm{AA}_{5}$ Investment profit $\left(\mathrm{A}_{24}-\mathrm{A}_{26}\right)$ & $\begin{array}{l}A_{24} \text { Pursuit of profit, } A_{25} \text { Cost reduction, } A_{26} \text { Technological } \\
\text { progress }\end{array}$ \\
\hline $\mathrm{AA}_{6}$ Agricultural assistance $\left(\mathrm{A}_{27}-\mathrm{A}_{29}\right)$ & $\begin{array}{l}\mathrm{A}_{27} \text { Technological progress, } \mathrm{A}_{28} \text { Market development, } \mathrm{A}_{29} \\
\text { Agricultural trade }\end{array}$ \\
\hline $\mathrm{AA}_{7}$ Geopolitics $\left(\mathrm{A}_{30}-\mathrm{A}_{32}\right)$ & $\begin{array}{l}\mathrm{A}_{30} \text { Diplomatic relations, } \mathrm{A}_{31} \text { Geopolitical influence, } \mathrm{A}_{32} \\
\text { International status }\end{array}$ \\
\hline $\mathrm{AA}_{8}$ Social economy $\left(\mathrm{A}_{33}-\mathrm{A}_{37}\right)$ & $\begin{array}{l}A_{33} \text { Resource, } A_{34} \text { Cost of production, } A_{35} \text { Investment } \\
\text { demand, } A_{36} \text { Agricultural product demand, } A_{37} \text { Food security }\end{array}$ \\
\hline $\mathrm{AA}_{9}$ International environment $\left(\mathrm{A}_{38}-\mathrm{A}_{41}\right)$ & $\begin{array}{l}\mathrm{A}_{38} \text { Agricultural product market, } \mathrm{A}_{39} \text { Resource shortages, } \mathrm{A}_{40} \\
\text { International food prices, } \mathrm{A}_{41} \text { Energy security }\end{array}$ \\
\hline $\mathrm{AA}_{10}$ Industry development $\left(\mathrm{A}_{42}-\mathrm{A}_{48}\right)$ & $\begin{array}{l}\mathrm{A}_{42} \text { Agricultural development, } \mathrm{A}_{43} \text { Industrial transformation, } \\
\mathrm{A}_{44} \text { Industry competition, } \mathrm{A}_{45} \text { Poverty reduction, } \mathrm{A}_{46} \\
\text { Agricultural technology, } \mathrm{A}_{47} \text { Management method, } \mathrm{A}_{48} \\
\text { Agricultural trade }\end{array}$ \\
\hline $\mathrm{AA}_{11}$ National development $\left(\mathrm{A}_{49}-\mathrm{A}_{55}\right)$ & $\begin{array}{l}\mathrm{A}_{49} \text { Economic growth, } \mathrm{A}_{50} \text { Employment opportunities, } \mathrm{A}_{51} \\
\text { Market reform, } \mathrm{A}_{52} \text { Vicious competition, } \mathrm{A}_{53} \text { Environmental } \\
\text { pollution, } \mathrm{A}_{54} \text { Food distribution, } \mathrm{A}_{55} \text { Increase in taxes }\end{array}$ \\
\hline $\mathrm{AA}_{12}$ international influence $\left(\mathrm{A}_{56}-\mathrm{A}_{58}\right)$ & $\begin{array}{l}\text { A }_{56} \text { Resource allocation, } A_{57} \text { Market influence, } A_{58} \\
\text { Negotiation ability }\end{array}$ \\
\hline $\mathrm{AA}_{13}$ Support and guidance $\left(\mathrm{A}_{59}-\mathrm{A}_{62}\right)$ & $\begin{array}{l}\mathrm{A}_{59} \text { Training courses, } \mathrm{A}_{60} \text { Information exchange, } \mathrm{A}_{61} \\
\text { Subsidized insurance, } \mathrm{A}_{62} \text { Business contact }\end{array}$ \\
\hline $\begin{array}{l}\mathrm{AA}_{14} \text { Cooperation and communication } \\
\left(\mathrm{A}_{63}-\mathrm{A}_{66}\right)\end{array}$ & $\begin{array}{l}\mathrm{A}_{63} \text { South-South cooperation, } \mathrm{A}_{64} \text { Agricultural assistance, } \mathrm{A}_{65} \\
\text { International relations, } \mathrm{A}_{66} \text { Economic and trade negotiations }\end{array}$ \\
\hline $\mathrm{AA}_{15}$ Media guide $\left(\mathrm{A}_{67}-\mathrm{A}_{72}\right)$ & $\begin{array}{l}\mathrm{A}_{67} \text { Win-Win, } \mathrm{A}_{68} \text { Social responsibility, } \mathrm{A}_{69} \text { State-owned } \\
\text { enterprises, } \mathrm{A}_{70} \text { Resource plunder, } \mathrm{A}_{71} \text { Neocolonialism, } \mathrm{A}_{72} \\
\text { New imperialism }\end{array}$ \\
\hline
\end{tabular}

\subsection{Axial Coding}

The relationship between the various concept categories obtained by open decoding is relatively vague, and the overall picture and internal logic relationship of China's agricultural FDI has not yet been clearly presented. During the axial coding phase, the concept categories will be placed back into the original data. On the basis of a thorough understanding of the research situation and the research object, the relationship between each group of concept categories is established, and the core categories are obtained. After discussing various genus relations, a theoretical construction prototype based on the orientation of China's agricultural FDI action is established. This kind of theoretical prototype focuses on the status quo of China's agricultural FDI and solving its practical problems. The theoretical basis is the practical rationality of investors. According to the logical order of China's agricultural FDI, this paper summarizes 15 concept categories into four core categories, namely, characteristics, reasons, impacts, and suggestions. "Characteristics" refers to the behavioral 
choices of the main stakeholders of China's agricultural FDI. "Reasons" refers to the motivations and strategic objectives of key stakeholders. "Impacts" refers to the impact of China's agricultural FDI on the agricultural, economic, and social aspects of China and the host country. "Suggestions" refers to the proposal to solve the problems and adverse effects of China's agricultural FDI, mainly aimed at the Chinese government and enterprises. For example, characteristics, one of the core categories, includes investment subjects, investment links, investment methods, and investment religions. These four factors are directly related to the characteristics of China's agricultural FDI (Figure 2). In the vertical direction, it can also be divided into three core categories of projects, countries, and the international community according to the micro, meso, and macroscopic mechanism of China's agricultural FDI. In order to facilitate the logic analysis, this paper selected four core categories of characteristics, reasons, impacts, and suggestions.

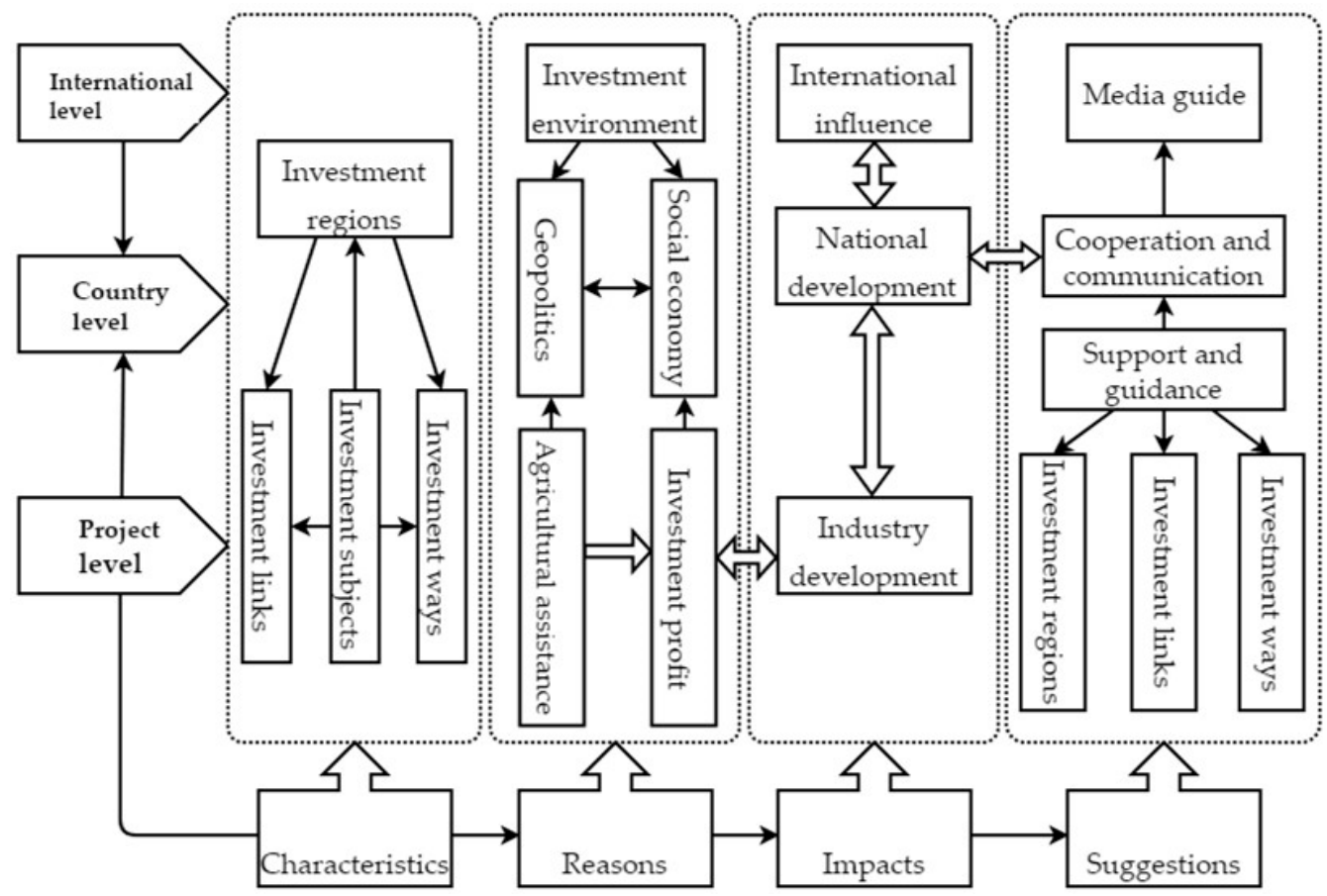

Figure 2. Conceptual model of China's agricultural foreign investment behavior logic.

\subsection{Model Construction and Analysis}

After two stages of analysis of open decoding and axial decoding, the various types of concept categories basically cover the characteristics, causes, and effects of China's agricultural FDI. The logical relationship between the core categories and the various concept categories has been relatively clear, and no new information needs to be explored to supplement the theoretical construction. Data collection can be stopped and model construction and analysis can be carried out.

\subsubsection{Characteristics of China's Agricultural FDI}

From the investment regions, China's agricultural FDI is mainly concentrated in developing projects mainly located in East Asia and the Pacific region [42]. In terms of the number of overseas enterprises, as of the end of 2016, 471 of the 863 agricultural enterprises established overseas were located in Asia, mainly in Laos, Indonesia, Cambodia and Thailand [43]. In terms of investment scale, the investment flows and investment stocks in Asia are more than 50\%, which is the largest share of the six continents. Obviously, geo-relationships are an important consideration for the regional distribution of agricultural investment in China. In the investment process, most enterprises will give priority to geographically adjacent neighboring countries and regions. China regards it as an important base for transnational operations of enterprises, thereby accumulating experience and reducing investment 
risks to a certain extent. In comparison, China's agricultural investment in developing countries such as Africa and Latin America is slightly insufficient, but cannot be ignored. China has been among the top ten investors in Mozambique [4], and China has rapidly emerged as the largest trading and investment partner in Africa [11]. As of the end of 2016, China's agricultural investment stock in Africa accounted for $8.1 \%$, and the investment stock in South America only accounted for 3.5\% [43]. At the micro level, the infrastructure and agricultural technology in these areas are lagging behind. If companies invest in these countries, the cost of the initial investment is higher. At the macro level, although these regions are rich in resources, they are poorly governed [7]. In addition to facing high political, economic, and legal risks, enterprises will also bear the pressure of international public opinion. It should also be noticed that China's agricultural investment is also concentrated in some developed countries, such as Singapore, New Zealand, and the United States [44]. On the one hand, the institutional conditions of these countries and the overall stability of the macro economy have attracted Chinese corporate investment [45]. On the other hand, Chinese companies can learn from their advanced technology and management experience to expand their market share. The distribution of Chinese agricultural FDI is shown in Figure 3 and Table 4.
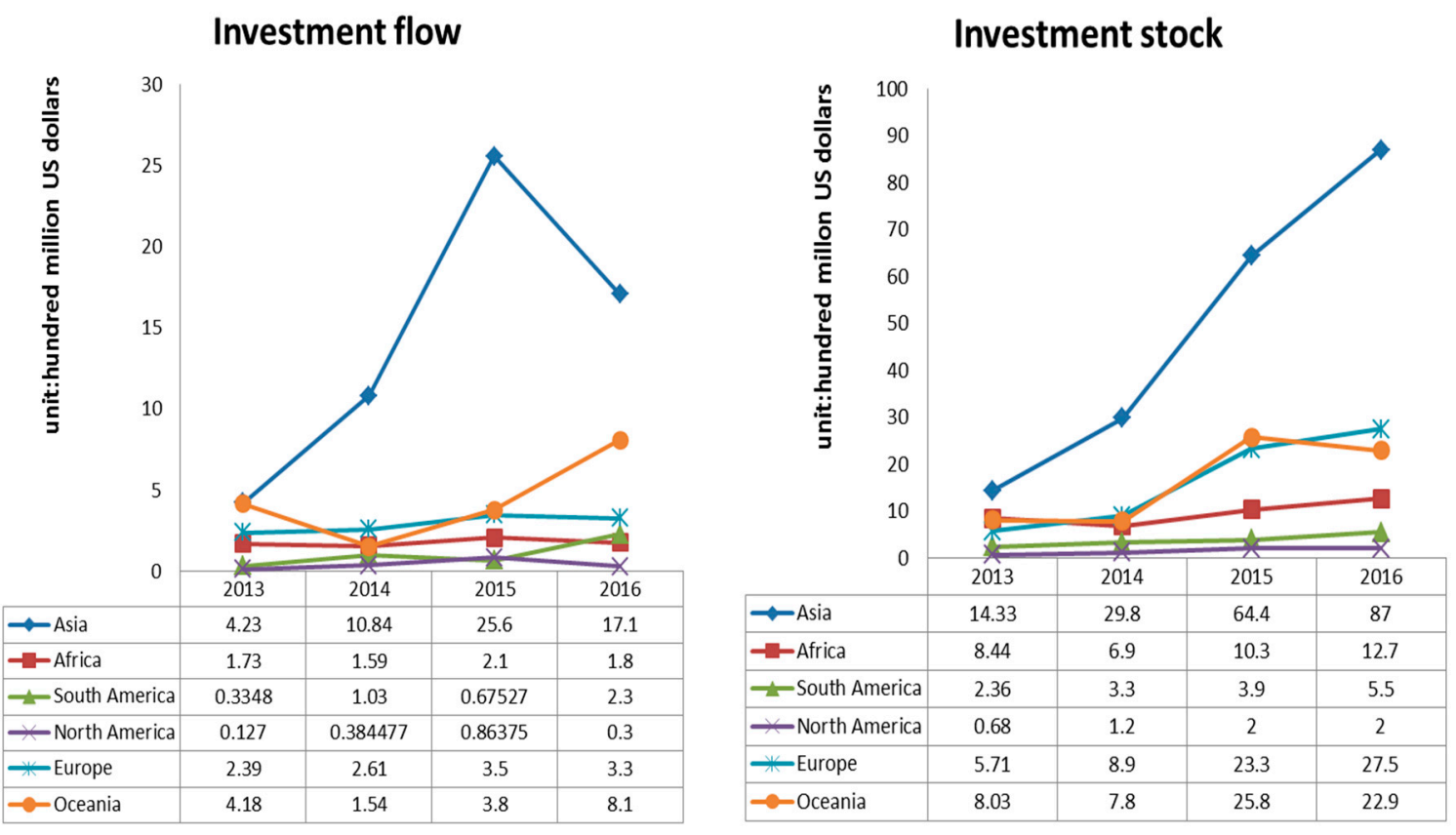

Figure 3. Distribution of China's agricultural FDI.

Table 4. Key countries of China's agricultural FDI in 2016 [43].

\begin{tabular}{cccc}
\hline \multirow{2}{*}{ Continent } & Country (Region) & $\begin{array}{c}\text { Investment Flow } \\
\text { (Unit: Ten Thousand U.S. Dollars) }\end{array}$ & $\begin{array}{c}\text { Investment Stock } \\
\text { (Unit: Ten Thousand U.S. Dollars) }\end{array}$ \\
\hline \multirow{2}{*}{ Asia } & Singapore & $76,537.4$ & $257,492.9$ \\
& Thailand & $19,728.7$ & $56,534.6$ \\
\hline \multirow{2}{*}{ Europe } & Netherlands & 557.9 & $130,991.9$ \\
& Russia & $28,996.1$ & $91,393.3$ \\
\hline \multirow{2}{*}{ Oceania } & Australia & $36,180.3$ & $134,773.0$ \\
& New Zealand & $44,817.5$ & $83,795.8$ \\
\hline \multirow{2}{*}{ Africa } & Tanzania & 428.4 & $14,417.9$ \\
& Mauritania & 6064.0 & $13,030.0$ \\
\hline \multirow{2}{*}{ South America } & Brazil & $20,293.3$ & $38,076.6$ \\
& Peru & 952.0 & 1682.8 \\
\hline \multirow{2}{*}{ North America } & United States & 2067.1 & $10,859.7$ \\
& Canada & 322.3 & 8800.2 \\
\hline
\end{tabular}


From the perspective of investment subjects, private enterprises are the mainstay of China's agricultural FDI, and many small companies from rising powers are also moving into Africa [10]. Judging from the number of domestic enterprises, there are 43 state-owned enterprises and 630 private enterprises engaged in agricultural FDI. As shown in Table 5, the number of private enterprises far exceeds that of state-owned enterprises. In terms of investment scale, from 2013 to 2016, the investment scale of private enterprises increased at an average annual rate of $21.1 \%$. In 2016, domestic private enterprises invested a total of 1.92 billion dollars, accounting for $58.7 \%$ of agricultural FDI flows [43], private agribusiness, especially in the input supply and service sector, is important, and can be expected to grow over time [10]. As an effective complement to the weak areas of state-owned enterprises' agricultural FDI, private enterprises have the advantages of flexible investment, specialization, and limited restrictions [46]. However, it faces problems such as shortage of financial strength and poor ability to resist risks. It is undeniable that state-owned enterprises occupy an important position in China's agricultural FDI [47]. Although the number of state-owned enterprises is small, investment flow accounts for nearly $50 \%$ of the total, the state-owned enterprises are heavily involved in overseas investment [42]. The advantage of state-owned enterprises lies in rich experience and strong ability to integrate resources in overseas investment [47]. But they are subject to more government supervision, inflexible management systems, and less investment awareness. These are all problems that state-owned enterprises need to solve urgently in the investment process. In addition, China's agricultural FDI also involves some individual investors, research institutes, banks, and investment funds [12,46]. Among them, China Exim Bank and China Development Bank have provided large loans to African countries [46], which played an important role in solving the financing problems faced by Chinese companies in investing in foreign agriculture, and promoted the smooth implementation of investment projects.

Table 5. Investment subjects of China's agricultural FDI.

\begin{tabular}{clccc}
\hline $\begin{array}{c}\text { Investment } \\
\text { Subjects }\end{array}$ & \multicolumn{1}{c}{ Scale } & $\mathbf{2 0 1 4}$ & $\mathbf{2 0 1 5}$ & $\mathbf{2 0 1 6}$ \\
\hline \multirow{2}{*}{$\begin{array}{c}\text { State-owned } \\
\text { enterprises }\end{array}$} & Number (as of the end of the year) & 41 & 34 & 43 \\
& Investment Flow (unit: hundred million US dollars) & 2.69 & 14.7 & 13.5 \\
& Investment stock (unit: hundred million US dollars) & 13.4 & 65.8 & 75.0 \\
\hline \multirow{3}{*}{ Private enterprises } & Number of (as of the end of the year) & 361 & 568 & 630 \\
& Investment flow (unit: hundred million US dollars) & 15.3 & 21.6 & 19.3 \\
& Investment stock (unit: hundred million US dollars) & 42.3 & 61.9 & 80.0 \\
\hline
\end{tabular}

From the perspective of investment links, China's agricultural FDI is mainly concentrated in planting. As far as the scale of investment is concerned, as of the end of 2016, the stock of FDI in the crop industry was 7.34 billion dollars, accounting for 46.6\% [43]. As far as the number of enterprises is concerned, there were 413 enterprises engaged in agricultural production. Overseas investment in crop farming is mainly distributed in Asia and Europe [44], such as Singapore, Russia, and other countries. The agricultural products produced by enterprises are mainly crops such as corn and rice, and economic crops such as natural rubber, sugar cane, and soybean. At the same time, it should be noted that China has 172 processing enterprises, 160 warehousing companies, and 128 logistics companies. Among them, there are 85 companies operating in four businesses at the same time [43]. It can be seen that although most enterprises are still in the low-end part of the industrial chain and the degree of industrial chain integration is relatively low, the focus of enterprise development has shifted to the whole industry chain construction $[44,48]$, gradually lengthened the agricultural industry chain. With the advancement of the go-out strategy, China is participating in the global agricultural market with a more active attitude [21], and hopes to gain profit and price influence through the entire industry chain operation [44]. The industrial structure and industrial chain construction of China's agricultural FDI are shown in Figure 4 and Table 6. 


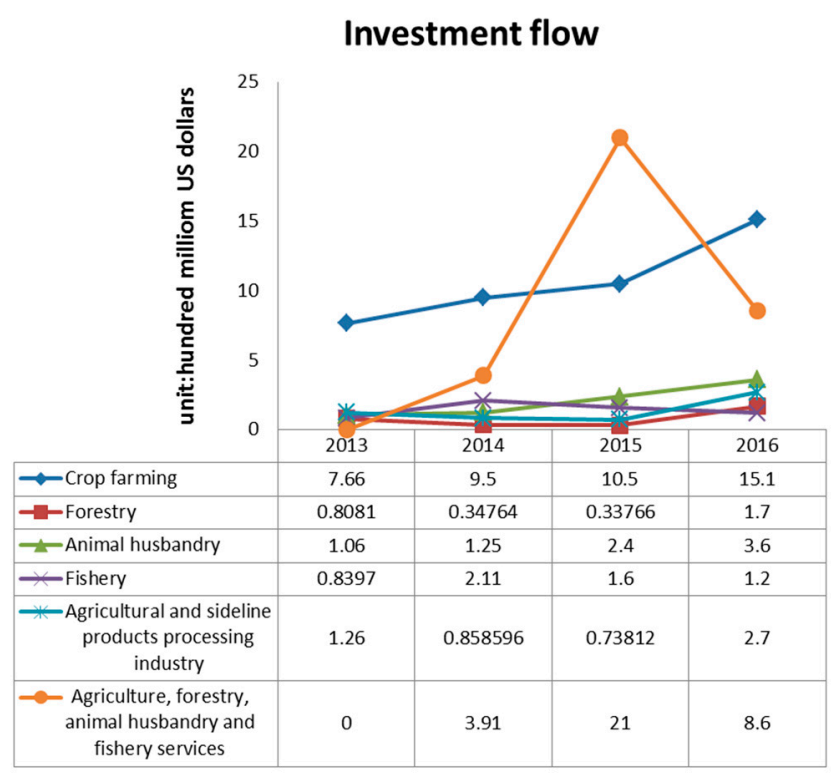

Figure 4. Industrial structure of China's agricultural FDI.

Table 6. Construction of China's agricultural FDI industry chain.

\begin{tabular}{cccc}
\hline Number of Companies & $\mathbf{2 0 1 4}$ & $\mathbf{2 0 1 5}$ & $\mathbf{2 0 1 6}$ \\
\hline 1. production & 256 & 410 & 413 \\
2. processing & 121 & 181 & 172 \\
3. Warehousing & 77 & 148 & 160 \\
4. Logistics & 57 & 126 & 128 \\
other & 128 & 319 & 311 \\
Operating both 1 and 2 & 28 & 143 & 137 \\
Operating 1, 2, and 3 & 12 & 103 & 101 \\
Operating 1, 2, 3, and 4 & 46 & 80 & 85 \\
\hline
\end{tabular}

From the perspective of investment methods, China's agricultural FDI methods are diversified and vary according to local environment, regulatory systems, and government policies. Chinese companies initially engaged in agricultural production by purchasing and leasing land. In order to alleviate the contradiction between the growing domestic demand for agricultural products and the shortage of agricultural resources, some Chinese enterprises purchase or lease land to countries with relatively abundant land resources and establish overseas agricultural production bases [15]. Small and medium-sized enterprises often use this model for agricultural production activities and employ local people to grow crops. The number of local employees depends on the size of the project. The lease term can vary from country to country, usually 15 or 20 years, and long term can reach more than 99 years [49]. Land leasing has always been the most commonly used model in China's agricultural investment projects, but its risks are high [7]. In addition to seeking land for agricultural production, Chinese investors are also implementing a contract farming model [7]. Investors will provide local farmers with inputs to grow certain crops, as companies provide farmers with seeds, fertilizers, and agricultural machinery [10], and agree to purchase agricultural products from these farmers $[10,50]$. Some people think that this method may increase the income of small-scale farmers and connect them to the market [50]. Others believe that in the case of a weak legal system, small farmers have weak negotiating skills, and if they do not understand the terms of the contract, they may suffer losses, and it involves mechanisms that comply with established quality standards and timely delivery [7]. Unlike the land leasing model, the contract farming model does not require local farmers to provide land for investors. For large companies with rich overseas operations, these companies are more focused on participating in overseas agricultural production activities in the form of brownfield 
investments, such as mergers and acquisitions. Especially after experiencing the global sub-prime crisis and the food crisis, many large foreign companies have been hit and the valuation has become lower. Some large domestic enterprises with strong financial strength seized the opportunity to participate in cross-border agricultural investment cooperation through mergers and acquisitions [10]. Throughout the development process of China's agricultural FDI, this change in investment mode further reflects the company's strength in the process of "going global".

\subsubsection{Reasons for China's Agricultural FDI}

From the perspective of the international macro environment, resources such as land and water are increasingly scarce on a global scale. In the context of global competition for natural resources, governments are actively investing in overseas agriculture to ensure domestic food and energy demand [11], and food security is again becoming an area of great concern for China [12]". In addition, China's food expenditure ratio is high [15], and part of the reason for shifting to overseas investment is to reduce the impact of global food price volatility and dependence on the global agricultural market [51]. At the enterprise level, as China's agricultural imports increase, Chinese companies' FDI decisions are based in part on the pursuit of profit, and they pursue long-term stable returns [11]. For example, the benefits of biofuel feedstock cultivation is an important incentive for private investment in some projects [46]. Foreign investment in many companies mixes agricultural aid and business objectives. With the in-depth promotion of the "One Belt, One Road" initiative, the Chinese government encourages companies to further develop foreign aid investment in less developed countries as an important part of the initiative [44]. The reasons for China's agricultural FDI, whether it is influenced by the international environment or the motive of enterprises to pursue profits, are ultimately based on the consideration of the national strategic level.

China's agricultural FDI policy is both politically sensitive and economically strategic [15]. For China, in terms of social economy, China has been constrained by resources after several decades of rapid growth, and domestic agricultural production costs have increased [42]. In order to meet the growing demand for agricultural products [44], China must rely not only on the domestic market, but also on the international market to provide much-needed raw materials and agricultural resources to make up for the gap between supply and demand [48]. China's policies in Africa have become less determined by geopolitical considerations and more by economic prospects [10]. In terms of geopolitics, China hopes to maintain good bilateral relations with developing countries at the social, economic, and political levels through agricultural aid and agricultural investment $[4,10,46]$. This kind of agricultural assistance and agricultural investment, driven by strong diplomatic relations, will also establish a responsible image of China. It is an important link to maintain geopolitical influence and can enhance China's international status [46,52]. A strong diplomatic push to assert geopolitical influence is central, and aid and investment is seen as part of this [52]. For the host country, these countries are rich in land resources, but its level of food production is low and its domestic investment capacity is insufficient, so there is considerable demand for the introduction of foreign agricultural investment $[7,42]$. Africa has long waited for investment in agriculture and associated productive sectors [52]. China has helped to promote the development of the agricultural sector in developing countries by providing funds and using agricultural technology to stimulate its agricultural production potential [10]. This can promote economic development and improve the welfare of the people of the host country [19]. Therefore, China's agricultural investment in these countries is in line with the objective needs of economic development in China and developing countries.

\subsubsection{The Impacts of China's Agricultural FDI}

Local governments are often sensitive to foreign investment in agriculture because it involves many issues, such as the security of land ownership, farmers' livelihoods, food security, and poverty $[4,7]$. At the investment project level, some scholars and experts believe that agricultural overseas investment is a resource plunder. In particular, large-scale overseas land investments offset the 
effects of poverty reduction measures [53], undermining the interests of small farmers and endangering local food security $[17,54]$, pursuing land acquisitions that are in violation of human rights, without prior consent of the preexisting land users [54]. However, some studies have shown that China's agricultural investment in the host country has significantly improved the level of local food security and cooperated with local small farmers through contract farming, which is in the interest of local small farmers [4,42,52]. China's agricultural technology and management methods are more in line with the actual needs of developing countries $[55,56]$, because of their recent experiences of development, their technological capacity, and the similar agro-ecological conditions, they have much to offer [52]. By the end of 2016, Chinese companies had directed local farmers to carry out agricultural production for a total of 362,941 people [43]. In addition, China's market demand may also bring profits and business opportunities to farmers in developing countries [46,50]. China's agricultural investment can not only develop crops suitable for China's needs [4], but also expand the market share of agricultural products in developing countries in China [15], and promote the development of the agricultural sector and agricultural trade in the host country [57].

From the standpoint of national development, overseas investment from China is both an opportunity and a challenge for the host country [19]. Some scholars believe that Chinese companies are concentrated in countries with abundant resources and poor social governance [58], which seek profits through disorderly vicious competition $[59,60]$ and selective bypassing of regulations by Chinese investors have been noted by many commentators [57], and ignoring the environment cost $[59,61]$ with no consideration of the social and environmental impacts [52] and distribution of food produced $[55,62,63]$. There are also many locals who worry that Chinese investors may bring technology, resources, and employment opportunities back to China and adversely affect local businesses, thus undermining the sustainable development of the local economy [64]. The social benefits of China's agricultural FDI are shown in Table 7. The positive impact of China's agricultural investment is first reflected in the ability to create jobs directly in relevant industries and markets [50], and the plantations generated some employment opportunities for daily wage work [60]. According to Chinese official statistics, as of the end of 2016, Chinese agricultural enterprises overseas employed a total of 147,292 people in the host country [43]. This has made an important contribution to reducing hunger and poverty in developing countries. Second, the development of the agricultural sector in the host country can increase taxes for the government. As of the end of 2016, the total income of Chinese agricultural enterprises overseas is 54.82 billion dollars, and a total of 270 million dollars of taxes are paid to the host country [43]. In turn, host governments can use increased taxes to support agricultural development, improve infrastructure, and promote market structure reforms, and to some extent solve the problem of lack of funds in the agricultural sector.

Table 7. Social benefits of China's agricultural FDI.

\begin{tabular}{lcccc}
\hline & $\mathbf{2 0 1 3}$ & $\mathbf{2 0 1 4}$ & $\mathbf{2 0 1 5}$ & $\mathbf{2 0 1 6}$ \\
\hline Total number of employed people in the host country & 59,688 & 125,912 & 110,684 & 147,292 \\
Total tax (unit: hundred million US dollars) & 1.12 & 0.78 & 3.2 & 2.7 \\
\hline
\end{tabular}

In the long run, China's overseas investment in agriculture will have a profound impact on China's own development and global economic development. At the micro level, China's agricultural FDI not only brings profits to enterprises [11], but also satisfies the domestic demand for certain agricultural products that are in short supply, and promotes the export of surplus agricultural products, such as agricultural machinery in China [10]. There is a gradual rise of African commercial farms making use of Chinese agricultural inputs and creating demand for Chinese agricultural products [10]. At the macro level, on the one hand, as an important part of the "One Belt, One Road" initiative, the goal of China's agricultural FDI is to gain greater voice in the global farm products market, open up new markets for Chinese products, and further enhance China's influence on the international stage [44]. On the other hand, China's increasing price influence and control over the industrial chain will 
promote further investment in trade, logistics, and commodity markets [44]. This will form a positive feedback. At the same time, it is in the interest of the whole world to raise the level of agricultural productivity in developing countries. China's agricultural investment will help target countries improve their investment capacity and promote local economic development, thereby increasing global food production and ensuring global food security $[55,56,65,66]$. China is an increasingly influential actor within the global food and nutrition security network [65].

\subsubsection{Suggestions on China's agricultural FDI}

From the perspective of investment regions, the Association of Southeast Asian Nations, Russia, Central Asia, and other friendly countries along the "Belt Road" and have become hot regions for attracting Chinese investment because of their resources, geography, humanities, and political economy. In addition to consolidating investment in the region, China should also focus on areas such as Africa, Latin America, and other areas where food production capacity and infrastructure construction need to be improved but which have high investment potential [42]. However, the governance of these developing countries is weak, and more emphasis should be placed on preventing economic, political, and legal risks in the investment process [48]. From the perspective of the investment chain, the number of enterprises and funds invested in the production process is the most, followed by processing. This shows the imbalance of China's agricultural FDI links. Key enterprises should develop in the direction of crossing agricultural enterprise groups, and gradually shift their investment focus from the production field to the high-end links of processing, acquisition, storage, transportation, and sales, and strengthen the core competitiveness of enterprises and integrate into the world value chain benefit distribution. From the perspective of investment methods, a common criticism of Chinese investors in the international community is that there is no full communication with local people and resource plundering of less developed countries [48]. Therefore, companies should keep in touch with local personnel before making investment decisions or in the investment process, so that they can understand the progress of the project and eliminate the concerns or dissatisfaction of local businesses and people. At the same time, Chinese companies should abide by local laws and regulations, respect local customs and beliefs, adopt fair, inclusive, localized business models and investment methods without land ownership transfer [42]. They need to understand how land tenure systems work and the underlying social and cultural practices in relation to development and governance [56]. This helps promote the harmonious development of the economy, the environment, and the local community, thus achieving a win-win goal.

The role of the government in promoting agricultural FDI cannot be ignored. Firstly, in order to cope with the complicated international environment, the Chinese government should strengthen the building of international relations and promote the implementation of foreign aid. China and the host country can use the economic and trade negotiations to understand each other's demands and make China's agricultural investment model adapt to local agricultural production, so that investment projects can bring profits to investors and bring economic and social benefits to the local [52]. Secondly, while implementing the agricultural outbound strategy, we should also pay attention to improving China's domestic grain production capacity, which is the prerequisite for achieving China's food security [42]. Thirdly, in order to improve the efficiency of agricultural FDI, the Chinese government should increase its support for "going global" enterprises. In addition to the establishment of training courses, information exchange centers, and subsidized insurance [42], the government should strengthen the links between enterprises and form a "going global" situation throughout the entire industry chain. This will not only solve market sales problems, but also form aggregate effects from financing, government support, and other aspects. Lastly, considering the profitability of the company and the imperfect regulatory system of the target country, China needs to further develop the mechanism for the enterprise to go global and guarantee the sustainable development of the project and ensure the effective implementation of the mechanism. 


\section{Conclusions and Discussion}

This paper systematically analyzes the characteristics of China's agricultural foreign investment, the reasons for investment, the impact on the agriculture and national development of the host country, and the inherent logic between them from the micro, meso, and macro dimensions. From the perspective of investment regions, China's agricultural FDI is concentrated in Asian developing countries and a few developed countries such as Singapore, New Zealand, the United States, and Australia. The investment scale in Latin America and Africa is relatively small. From the perspective of investment models, China's agricultural investment models are diverse, and are gradually shifting from land leasing to mergers and acquisitions. On the one hand, this shift in investment patterns reflects that companies are evading high-risk investment methods based on land ownership transfer and paying more attention to protecting farmers' livelihoods. On the other hand, Chinese companies investing in circulation and sales have also strengthened the connection between local farmers and the market, and guaranteed food security in developing countries. From the perspective of investment motives, China's participation in global agricultural investment reflects China's political and socio-economic demands. It is driven by factors such as the company's motives for profit, national food security strategies, and government seeking diplomatic support.

China's agricultural FDI has met the development needs of China and developing countries to a certain extent. For China, foreign investment in agriculture can enable enterprises to make profits and expand the market for agricultural products. It helps to ensure national food security and achieve China's geopolitical and socio-economic development goals. For the host country, China's agricultural FDI provides technology and a broad market for developing countries, and promotes agricultural productivity in these countries. The development of the agricultural industry in these countries will also create spillover effects through channels such as increasing employment and taxation, thereby promoting the sustainable development of these countries. The increased taxes and employment in developing countries can in turn be used to promote higher levels of agricultural production and thus attract Chinese investment. This will become a new cooperative development model and form a chain of interests that meets the needs of both China and developing countries.

However, there are still gaps in the actual effects and objectives of China's agricultural investment. At the enterprise level, the investment model of land leasing has damaged the interests of local farmers to a certain extent, and the excessive pursuit of profits by Chinese companies may lead to the unfair distribution of agricultural products. This has led to many reports on the negative impact of Chinese agricultural investment. At the government level, due to inadequate infrastructure and inadequate institutions in most developing countries, this has increased the investment costs and risks of enterprises, making many projects unsustainable. In order to achieve a win-win goal, from the enterprise perspective, it is necessary to rationally plan the investment layout and balance the development needs of itself and the target country. In addition, a sustainable investment model should be implemented and cooperation between enterprises should be strengthened. From the government perspective, the first step is to promote the building of international relations and comprehensively use aid, investment, trade, and other means to carry out "South-South cooperation." Second, while implementing agricultural FDI, it is necessary to develop domestic agricultural production. This is mainly because the current international public opinion challenges China's agricultural foreign investment motives; that is, China uses agricultural investment to plunder resources, in order to meet its own food security. Therefore, improving domestic agricultural production capacity and realizing food self-sufficiency should be the premise of agricultural foreign investment. In that way, it can reasonably respond to the doubts of international public opinion and create a good investment environment for Chinese enterprises. The third is to strengthen the guidance and support for enterprises, improve the institutional mechanism for agricultural development, and ensure the progress of investment projects. From the perspective of the international community, on the one hand, the formulation and improvement of international rules should be strengthened to create a suitable environment for international agricultural investment. On the other hand, public 
opinion guidance should be strengthened to make the public aware of the necessity of introducing agricultural investment in developing countries, and to objectively view the impact of agricultural FDI. With gradual improvement of the international rules, the increase of government support, and the enhancement of corporate strength, the positive effects of China's agricultural investment on China and the host country will continue to be highlighted. As long as China's agricultural FDI meets the development model and needs of the target country, the negative effects it brings will be greatly reduced, and finally achieve a win-win goal.

Compared with other current research, this paper chooses the grounded theory method, based on literature. The impact of China's agricultural FDI on the host country involves political, economic, and social aspects. Some indicators are difficult to quantify. Therefore, our main goal was to do a literature analysis, review the views of other researchers, and form a rational understanding of China's agricultural FDI. In terms of structure, this method can not only explain the actual impact of China's agricultural FDI, but also clearly show its causes and consequences, and form a rational understanding of China's agricultural foreign investment behavior. In terms of content, this paper combines many different viewpoints and analyzes them from the micro, meso, and macro dimensions. Compared with the case study methods mainly used in the current research, the conclusions drawn by this method have more general applicability. Inevitably, with this research method it is difficult to include all relevant literature in the scope of this analysis, with a certain degree of subjectivity. However, large sample analysis based on many academic articles and media reports from different countries and different perspectives can solve this problem better, making the research results obtained in this paper more objective. At the theoretical level, the development path of China's agricultural FDI is in line with the mode proposed by Cantwell's technological competence theory, from neighboring countries to developing countries to developed countries. Additionally, China's agricultural FDI in developing countries has capital and technological advantages, which to a certain extent also conforms to the monopoly advantage theory. Because China's agricultural FDI is partly politically motivated, in addition to economic benefits, China's agricultural FDI is also driven by other non-economic factors, such as ensuring national food security and consolidating and developing diplomatic relations. Additionally, as agricultural FDI is more resource-oriented and faces higher risks, this makes the actual situation of China's agricultural FDI more complicated than theory. Theoretical research on FDI in the agricultural sector in developing countries needs to be strengthened. At the practical level, for the actual effects and impacts of Chinese agricultural FDI, in-depth qualitative and quantitative research is still needed. In the future, we will use more empirical research methods to cross-validate the influencing factors and investment layout changes of China's agricultural FDI to obtain more reliable research results. As for how to solve the current problems faced by China's agricultural FDI, more on-the-spot investigations and investment project evaluations are needed to study the investment cooperation model that suits the interests of both parties in order to achieve a win-win goal.

Author Contributions: X.J. carried out model analysis and contributed to writing the paper. Y.C. contributed to the design of the article framework, reviewed the literature and discussion, and provided advice on results. L.W. provided resources and reviewed the literature. All authors have read and approved the final manuscript.

Funding: This research was funded by National Natural Science Foundation of China, grant number 41871109\& 41471115, and The Agricultural Science and Technology Innovation Program, grant number ASTIP-IAED-2018.

Acknowledgments: Special thanks are given to five anonymous reviewers for their insightful and constructive suggestions.

Conflicts of Interest: The authors declare no conflict of interest.

\section{References}

1. Raymond, J.; Kassim, N.; Rose, J.W.; Morris, A. Context-specific food-based approach for ensuring nutrition security in developing countries: A review. Int. J. Food Sci. Nutr. 2018, 69, 410-416. [CrossRef]

2. Nzabuheraheza, F.D.; Nyiramugwera, A.N. Food security status in developing countries: A case study of Burera and Musanze Districts of Rwanda. Afr. J. Food Agric. Nutr. Dev. 2017, 17, 12413-12426. [CrossRef] 
3. FAO; IFAD; UNICEF; WFP; WHO. The State of Food Security and Nutrition in the World 2018: Building Climate Resilience for Food Security and Nutrition; FAO: Rome, Italy, 2018; pp. 1-201. ISBN 978-92-5-130844-8.

4. Chichava, S.; Duran, J.; Cabral, L.; Shankland, A.; Buckley, L.; Lixia, T.; Yue, Z. Brazil and China in Mozambican agriculture: Emerging insights from the field. IDS Bull. 2013, 44, 101-115. [CrossRef]

5. Morea, D.; Balzarini, M. Financial sustainability of a public-private partnership for an agricultural development project in Sub-Saharan Africa. Agric. Econ. Czech 2018, 64, 389-398. [CrossRef]

6. Chen, Y.F.; Li, X.D. Resolving the international public opinion dilemma of overseas agricultural investment. China Dev. Observ. 2017, 46-52. (In Chinese) [CrossRef]

7. Kaarhus, R. Land, investments and public-private partnerships: What happened to the Beira Agricultural Growth Corridor in Mozambique? J. Mod. Afr. Stud. 2018, 56, 87-112. [CrossRef]

8. Pitcher, M.A. Transforming Mozambique: The Politics of Privatization, 1975-2000; Cambridge University Press: Cambridge, UK, 2008; pp. 1-320. ISBN 9780521052689.

9. Hall, R. The next Great Trek? South African commercial farmers move north. J. Peasant Stud. 2012, 39, 823-843. [CrossRef]

10. Amanor, K.S.; Chichava, S. South-South Cooperation, Agribusiness, and African Agricultural Development: Brazil and China in Ghana and Mozambique. World Dev. 2016, 81, 13-23. [CrossRef]

11. Amanor, K.S. Expanding Agri-business: China and Brazil in Ghanaian Agriculture. IDS Bull. 2013, 44, 80-90. [CrossRef]

12. Xu, X.L.; Li, X.Y.; Qi, G.B.; Tang, L.X.; Mukwerezab, L. Science, Technology, and the Politics of Knowledge: The Case of China's Agricultural Technology Demonstration Centers in Africa. World Dev. 2016, 81, 82-91. [CrossRef]

13. Gu, J.; Carty, A. China and African development: Partnership not mentoring. IDS Bull. 2014, 45, 57-69. [CrossRef]

14. Malone, A. How China's Taking over Africa, and Why the West Should Be very Worried. Daily Mail Online. Available online: https:/ / www.dailymail.co.uk/news/article-1036105/How-Chinas-taking-Africa-WestVERY-worried.html (accessed on 18 July 2008).

15. Brautigam, D.; Ekman, S.S. Briefing Rumours and realities of Chinese agricultural engagement in Mozambique. Afr. Aff. 2012, 111, 483-492. [CrossRef]

16. Carmody, P.R. The Rise of the BRICS in Africa: The Geopolitics of South-South Relations; Zed Books: London, UK, 2013; pp. 1-184. ISBN 1780326041.

17. Hofman, I.; Ho, P. China's 'developmental outsourcing': A critical examination of Chinese global 'land grabs' discourse. J. Peasant Stud. 2012, 39, 1-48. [CrossRef]

18. Cotula, L.; Vermeulen, S.; Leonard, R.; Keeley, J. Land Grab or Development Opportunity? Agricultural investment and international land deals in Africa; IIED/FAO/IFAD: London, UK; Rome, Italy, 2009; pp. 1-130. ISBN 978-1-84369-741-1.

19. Buckley, L. Chinese agriculture development cooperation in Africa: Narratives and politics. IDS Bull. 2013, 44, 42-52. [CrossRef]

20. Edelman, M. Messy hectares: Questions about the epistemology of land grabbing data. J. Peasant Stud. 2013, 40, 485-501. [CrossRef]

21. Brautigam, D. The Dragon's Gift: The Real Story of China in Africa: The Real Story of China in Africa; Oxford University Press: Oxford, UK, 2009; pp. 1-414. ISBN 978-0-19-955022-7.

22. Hymer, S.H. The International Operations of National Firms: A Studies of Direct Foreign Investment; MIT Press: Cambridge, MA, USA, 1976.

23. Kindleberger, C.P. American Business Abroad; Yale University Press: New Haven, CT, USA, 1969.

24. Vernon, R. International Investment and International Trade in the Product Cycle. Q. J. Econ. Act. 1966, 80, 190-207. [CrossRef]

25. Kojima, K. Direct Foreign Investment: A Japanese Model of Multinational Business Operations; Croom Helm: London, UK, 1978.

26. Dunning, J.H. Trade, Location of Economic Activity and the MNE: A Search for an Eclectic Approach. Int. Alloc. Econ. Act. 1977, 395-418. [CrossRef]

27. Buckley, P.J.; Mark, O.C. The Future of the Multinational Enterprise; Holmes and Melers: New York, NY, USA, 1976.

28. Rugman, A.M. Inside the Multinationals; Croom Helm: London, UK, 1987. 
29. Dunning, J.H. Trade, Location and the multinational enterprise: A neglected factor? J. Int. Bus. Stud. 1998, 40, 5-19. [CrossRef]

30. Porter, M.E. The Competition Advantage of Nations; The Free Press: New York, NY, USA, 1990.

31. Porter, M.E. Location, Competition and Economic Development: Local Clusters in a Global Economy. Econ. Dev. Q. 2000, 14, 15-35. [CrossRef]

32. Hill, C.W.L.; Hwang, P.; Kim, W.C. An Eclectic Theory of the Choice of International Entry Mode. Strateg. Manag. J. 1990, 11, 117-128. [CrossRef]

33. Bell, J.H.J. Single or Joint Venturing? A Comprehensive Approach to Foreign Entry Mode Choice; Avebury: Aldershot, UK, 1996.

34. Dunning, J.H. International Production and the Multinational Enterprise; George Allen and Unwin: London, UK, 1981.

35. Louis, T.W. Third World Multinationals: The Rise of Foreign Investment from Developing Countries; The MIT Press: Cambridge, MA, USA, 1983.

36. Lall, S.; Mohammad, S. Multinationals in Indian big business: Industrial characteristic of foreign investment in a heavily regulated economy. J. Dev. Econ. 1983, 13, 143-157. [CrossRef]

37. John, C. Technological Innovation and Multinational Corporations; B. Blackwell: Cambridge, MA, USA, 1989.

38. Wach, K.; Wojciechowski, L. Determinants of inward FDI into Visegrad countries: Empirical evidence based on panel data for the years 2000-2012. Econ. Bus. Rev. 2016, 2, 34-52. [CrossRef]

39. Glaser, B.G.; Strauss, A.L. The Discovery of Grounded Theory: Strategies for Qualitative Research; Aldine de Gruyter: New York, NY, USA, 1967; pp. 1-282. ISBN 0-202-30260-1.

40. Parry, K. Grounded theory and social process: A new direction for leadership research. Leadersh. Q. 1998, 9, 85-105. [CrossRef]

41. Halaweh, M. Using grounded theory as a method for system requirements analysis. JISTEM 2012, 9, $23-38$. [CrossRef]

42. Chen, Y.F.; Li, X.D.; Wang, L.J.; Wang, S.H. Is China different from other investors in global land acquisition? Some observations from existing deals in China's Going Global Strategy. Land Use Policy 2017, 60, 362-372. [CrossRef]

43. Ministry of Agriculture and Rural Affairs. Report on China's Agricultural Investment Cooperation (2017); China Agricultural Press: Beijing, China, 2018; pp. 1-104. ISBN 978-7-109-24006-3. (In Chinese)

44. Gooch, E.; Fred, G. China's Foreign Agriculture Investments; EIB-192; U.S. Department of Agriculture, Economic Research Service, April 2018. Available online: https:/ /www.ers.usda.gov/webdocs/publications/88572/ eib-192.pdf (accessed on 24 April 2018).

45. Kolstad, I.; Wiig, A. Better the devil you know? Chinese foreign direct investment in Africa. J. Afr. Bus. 2011, 12, 31-50. [CrossRef]

46. Helen, L.S. Understanding China's Agricultural Investments in Africa. Available online: https://www.files. ethz.ch/isn/146037/saia_sop_102_lei_sun_20111129.pdf (accessed on 30 November 2011).

47. Xu, X.L.; Qi, G.B.; Li, X.Y. Business Borderlands: China's Overseas State Agribusiness. IDS Bull. 2014, 45, 114-124. [CrossRef]

48. Margaret, M.; Guo, J. China's Agricultural Investment in Latin America: A Critical Assessment. Available online: https:/ / www.thedialogue.org/analysis/chinas-agricultural-investment-in-latin-america/ (accessed on 27 June 2015).

49. The High Level Panel of Expertson Food Security and Nutrition (HLPE). Land Tenureand International Investments in Agriculture; The Committee on World Food Security: Rome, Italy, 2011; Available online: http:/ / www.doc88.com/p-3137614708075.html (accessed on 31 July 2011).

50. Tada, M.; Hu, D.; Tokrisna, R. The Role of Foreign Direct Investment and Food Processing Industry toward High Value Agriculture in Asia-Cross Country Statistical Analysis and Farm Level Evidence. JARQ 2009, 43, 317-322. [CrossRef]

51. Li, X.; Qi, G.; Tang, L.; Zhao, L.; Jin, L.; Guo, Z.; Wu, J. Agricultural Development in China and Africa: A Comparative Analysis; Routledge: London, UK, 2012; pp. 1-316. ISBN 9781849713887.

52. Scoones, I.; Amanor, K.; Favareto, A.; Qi, G.B. A New Politics of Development Cooperation? Chinese and Brazilian Engagements in African Agriculture. World Dev. 2016, 60, 362-372. [CrossRef]

53. Naylor, R. Expanding the boundaries of agricultural development. Food Secur. 2011, 3, 233-251. [CrossRef] 
54. Rulli, M.C.; Saviori, A.; D'Odorico, P. Global land and water grabbing. Proc. Natl. Acad. Sci. USA 2013, 110, 892-897. [CrossRef] [PubMed]

55. Alden, C. China and the long march into African agriculture. Cahiers Agric. 2013, 22, 16-21. [CrossRef]

56. Zhao, Y. China-Africa development cooperation in the rural sector: An exploration of land tenure and investments linkages for sustainable resource use. Environ. Dev. Sustain. 2013, 15, 355-366. [CrossRef]

57. Mukwereza, L. Reviving Zimbabwe's Agriculture: The Role of China and Brazil. IDS Bull. 2013, 44, 116-126. [CrossRef]

58. Gu, J. The last golden land? Chinese private companies go to Africa. IDS Work. Pap. 2011, $2011,1-42$. [CrossRef]

59. Lagerkvist, J. As China returns: Perceptions of land grabbing and spatial power relations in Mozambique. J. Asian Afr. Stud. 2014, 49, 251-266. [CrossRef]

60. Friis, C.; Nielsen, J.Ø. Small-scale land acquisitions: Large-scale implications: Exploring the case of Chinese banana investments in northern Laos. Land Use Policy 2016, 67, 117-129. [CrossRef]

61. Assembe-Mvondo, S.; Cerutti, P.Q.; Putzel, L.; Eba'a Atyi, R. What Happens When Corporate Ownership Shifts to China? A Case Study on Rubber Production in Cameroon. Eur. J. Dev. Res. 2016, 28, 465-478. [CrossRef]

62. Adisu, K.; Sharkey, T.; Okoroafo, S. The impact of Chinese investment in Africa. Int. J. Bus. Manag. 2010, 5, 3-9. [CrossRef]

63. Akram-Lodhia, A. Contextualising land grabbing: Contemporary land deals, the global subsistence crisis and the world food system. Can. J. Dev. Stud. 2012, 33, 119-142. [CrossRef]

64. He, F.; Wang, B. Chinese interests in the global investment regime. China Econ. J. 2014, 7, 4-20. [CrossRef]

65. Fan, S.; Brzeska, J. Feeding more people on an increasingly fragile planet: China's food and nutrition security in a national and global Context. J. Integr. Agric. 2014, 13, 1193-1205. [CrossRef]

66. Morton, K. Learning by doing: China's role in the global governance of food security. SSRN Electron. J. 2012, 1-30. [CrossRef]

(C) 2018 by the authors. Licensee MDPI, Basel, Switzerland. This article is an open access article distributed under the terms and conditions of the Creative Commons Attribution (CC BY) license (http://creativecommons.org/licenses/by/4.0/). 